\title{
Spatial change detections and inventory of wetlands in Yenagoa Urban Area: Bayelsa State, Nigeria
}

\begin{abstract}
Yenegoa Town has in recent years witnessed rapid City growth and Urban development and much of these developments are unplanned and unregulated. This has seriously impacted on wetlands in several locations of the town as persistent Wetlands reclamations are being witnessed in study area. This prompted the need for the study which is aimed to map wetlands location in Yenagoa's urban area using GIS and Remote Sensing approach. The study analyzes land use/land cover changes (LULC) using LANDSAT(5) TM, LANDSAT(5) ETM and LANDSAT(7) OLI satellite imageries of 1990, 2000, 2010 and 2020 respectively. Through this study, the pattern of urban expansion for Thirty years were been studied. The satellite imageries covering the area were acquired and analyzed using ArcGIS 10.1 and ENVI 5.0 software. The supervised image classification method was adopted and the classification results were validated using the Kappa Index of Agreement (KIA) yielding an accuracy of $0.69 \mathrm{~m}$ for year $1990,0.62 \mathrm{~m}$ for year $2000,0.58 \mathrm{~m}$ for year 2010 and $0.73 \mathrm{~m}$ for 2020 . A total area of $13,741.4$ hectares was delineated in the study area which is identified as Yenagoa's urban area. After processing the imageries, four land use/land cover (LULC) classes where considered, and the results shows that Built-up area continuously increased in land area from 1990 -2020 with total percentage change of $273.31 \%(4,178.7 \mathrm{ha})$ and total annual rate of change of 25.33 . Vegetation have total percentage change of $38.55 \%(974.34 \mathrm{Ha})$ and total annual rate of change of 3.85 , wetland cover loss with total percentage Change of $61.96 \%(-51,44.99 \mathrm{ha})$ and total annual rate of change of $-6.19 \mathrm{ha}$, and the water body have loss of total percentage of $-2.16 \%(-8.05 \mathrm{Ha})$ and total annual rate of change of $-0.22 \mathrm{ha}$ wetland at Yenegwe loss by Total \%change of $-29.918 \%$ ( $-197.95 \mathrm{ha})$, and wetland at Igbogene loss by total percentage change of $-36.028 \%$ (-358.7ha). The research findings also revealed that the wetlands in Anyama, Swali, Kpansia and Opolo Towns were completely lost from the third Epoch of 2010, this may be as a result of persistence reclamation of wetland in this parts of the study area. The Markov Chain predicted model were utilized for predicting the likely changes in land use land cover for a period of thirty years. The predicted results also indicates that wetland size of $32.47, \%, 30.68 \%$ and $28.99 \%$ may likely be lost by the year 2030, 2040 and 2050 respectively in study area if no action is taking by concerned authorities to forestall the factors responsible for the lost in wetland. The study justified the dynamics of remote sensing and GIS techniques in modeling wetlands changees over these periods, wise use of wetland resources and improvement of institutional arrangement were recommended so that wetland policies can be fully integrated into the planning process across all disciplines.
\end{abstract}

Keywords: spatial, wetlands, ecosystem, urbanization, inventory

\author{
Volume 6 Issue 6 - 202
}

\author{
Elemuwa IC,' Lawrence Hart, ${ }^{2}$ Eze Promise \\ 13 \\ 'Department of Surveying and Geomatics, Rivers State \\ University, Nigeria \\ ${ }^{2}$ Lecturer and a research scientist, Department of Surveying and \\ Geomatics, Rivers State University, Nigeria \\ ${ }^{3}$ Research Scientist in Academics, Department of Surveying \\ and Geomatics, Faculty of Environmental Sciences, Rivers State \\ University, Nigeria
}

Correspondence: Eze Promise I, Department of Surveying and Geomatics, Rivers State University, Nkpolu-Oroworukwo, Port Harcourt, Rivers State, Nigeria, Email ezepromise4christ@gmail.com

Received: November 24, 202I | Published: December 07, 2021

\section{Introduction}

Wetlands are land that has areas of marsh, fen, peat land or water, whether natural or artificial, permanent or temporary, with water that is static or flowing, fresh, brackish or salt, including areas of marine water, the depth of which at low tide does not exceed six meters". 1,2 Wetlands also include a wide variety of inland habitats such as marshes, peat lands, floodplains, rivers and lakes, and coastal areas such as salt marshes, mangroves, intertidal mudflats and sea grass beds, and also coral reefs and other marine areas not deeper than six meters at low tide, as well as man -made wetlands such as dams, reservoirs, rice paddies and wastewater treatment ponds and lagoons. ${ }^{3-5}$

Urbanization remains a major threat to wetlands because as cities develop, rural areas in the urban fringes experience urban influences with an increased demand for land. Wetlands which serve as habitats to biodiversity are incrementally lost to urbanization and species become endangered and species that are foreign might be introduced into the environment (Hardman, 2011). It has been observed by most scholars that these wetlands have been degraded over time. Numerous factors have been identified to be responsible for the degradation of natural wetlands ecosystems in Nigeria especially in the Niger Delta region including Yenagoa Bayelsa State Nigeria. ${ }^{6}$ The most important among them are, land demand by a large population, a lack of understanding of wetland values, misguided policies, lack of environmental laulations, and water diversion needed because of rapid economic growth. ${ }^{7}$ The land use in Yenagoa's urban area has tremendously increased due to rapid population growth. However, the urban expansion in yenagoa has led to acquisition of more lands in the wetlands area and much of these urban expansions are unplanned and unregulated. Wetlands in Yenagoa's urban environment have been seriously affected by conversion to developmental uses such as residential, commercial, road network, pipeline, flow station, oil and gas facilities, flow lines, open and cleaned areas. However, no studies exist to show the spatial characteristics of wetlands in each of the communities in Yenagoa's urban area with respect to the level of degradation or loss, this prompted the need fo this study. The study is therefore aimed at detecting the changes in wetland of Yenagoa's urban area of Bayelsa State using spatial data processing 
techniques that will identify four classes of land-use/land-cover such as Vegetation, Wetland, Built-up and Water body, with the objectives of Determining the spatio-temporal changes of land-use/land-cover classes in the study area Analyzing the changes in wetlands in the study area from four epoch of 1990 to 2020; Prediction of the trend of wetland changes for the period of Thirty years using Markov chain predictive model; and to Show the surface flow direction of the terrain using Digital Elevation model (DEM).

\section{Study area}

Yenagoa is headquarters of Yenagoa Local Government Area and the state capital of Bayelsa State (NDDC, 2006). Geographically, Yenagoa L.G.A lies within latitudes $4^{\circ} 49^{\prime} \mathrm{N}$ and $5^{\circ} 23^{\prime} \mathrm{N}$ and also within longitudes $6^{\circ} 10^{\prime} \mathrm{E}$ and $6^{\circ} 33^{\prime} \mathrm{E}$ (Figure 1). It has a mean sea level elevation of $7.87 \mathrm{~m}-13.80 \mathrm{~m}$. The city is located on the banks of Ekole Creek and Nun River; the latter being one of the major river courses making up the Niger Delta's river system.

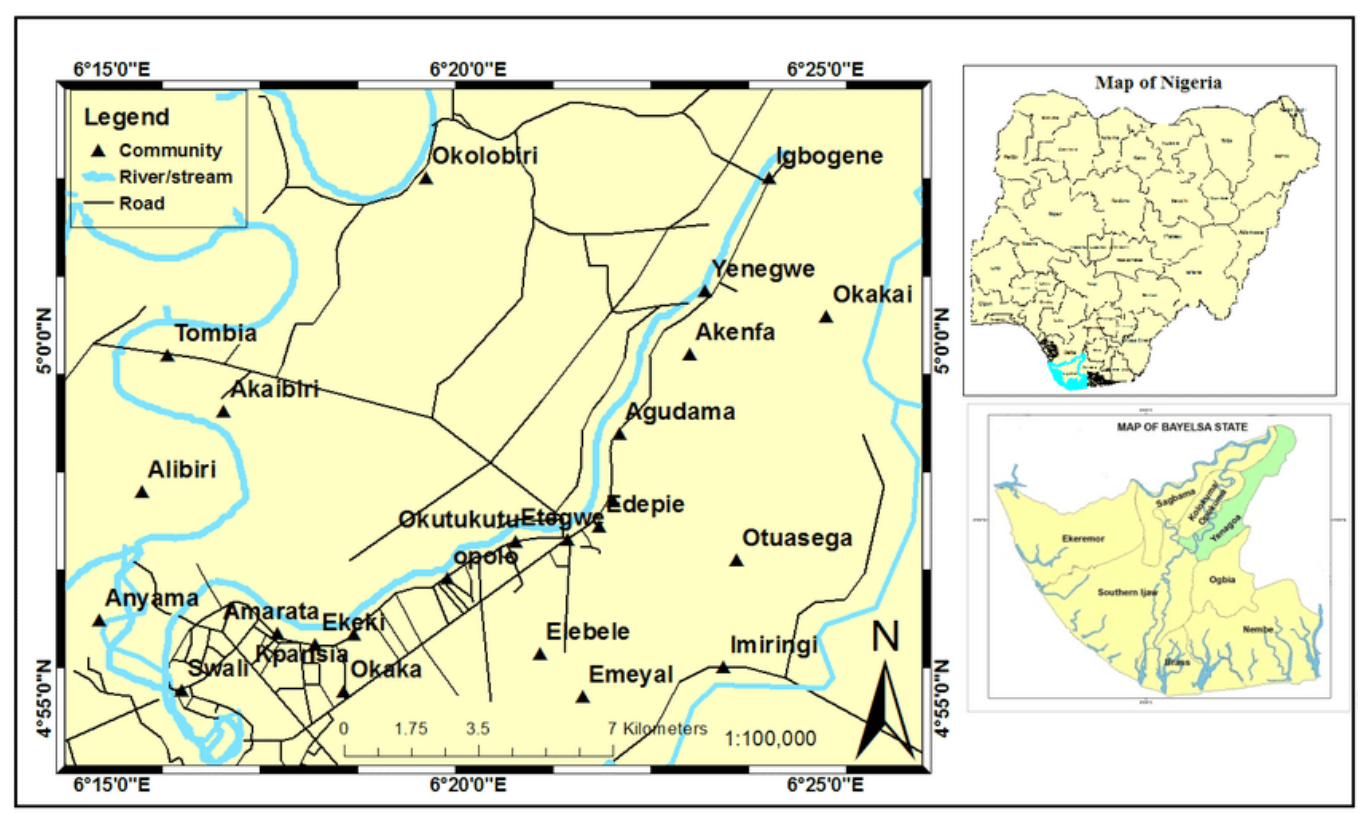

Figure I Yenagoa Showing study Communities.

\section{Materials and methods}

\section{Data acquisition and source}

Sources of data for this study was acquired from a time series of LANDSAT Thematic Mapper (TM) and Enhanced Thematic Mapper plus with Operational Land Imager (OLI) imageries and was used to generate land use and land cover maps of the study area. The data sets cut across epochs from 1990 to 2020. The raw satellite data was obtained from the archive of the United States Geological Survey and Earth Explorer. The maps were projected using Universal Transverse Mercator (UTM) zone 32N and WGS-84 datum (Table 1).

Table I Data source information

\begin{tabular}{llllllll}
\hline S/N & Satelite/ Data Type & SENSOR & $\begin{array}{l}\text { Date of } \\
\text { Acquisition }\end{array}$ & SACLE & Bands & Cloud cover & Source \\
\hline I & Landsat 5 & Landsat TM & $9 / 1 / 1990$ & $30 \mathrm{~m}$ & 1,2 and 3 & 0 & http://glovis.usgs.gov/ \\
2 & Landsat 5 & Landsat ETM & $20 / 01 / 2000$ & $30 \mathrm{~m}$ & 1,2 and 3 & 0 & http://glovis.usgs.gov/ \\
3 & Landsat 7 & Landsat OLI & $20 / 12 / 2010$ & $30 \mathrm{~m}$ & 2,3 , and 4 & 0 & http://glovis.usgs.gov/ \\
4 & Landsat 7 & Landsat OLI & $6 / 1 / 2020$ & $30 \mathrm{~m}$ & 2,3 , and 4 & 0 & http://glovis.usgs.gov/ \\
\hline
\end{tabular}

\section{Geo-referencing properties of the images}

The Geo-referencing properties of 1990, 2000, 2010 and 2020 made up of Universal Transverse Mercator (UTM) projection, and datum WGS 84, zone 32. Based on the prior knowledge of the study area for over 30 years and thorough ground-routing, a classification scheme was developed. ${ }^{1}$ The classification scheme developed gives a broad classification where the land use/land cover was identified by a single digit. Table 2 Shows the four-land use/land cover classification identified in the study area considering the scale and resolution of the remote sensor data, interpretation of more elements of the image such as color, texture, shadow, pattern, association, shape and size of the data (resource data) research objectives, field visit and the physical nature of the wetlands terrain in the study area.

This involved identifying a set of sample locations and conducting field visit to the study site on Monday 22nd June and Tuesday 7th July 2015 to validate these locations. The land use and land cover found were compared to that which was mapped in the image for the same locations. 
Table 2 Land use/land cover classification'

\begin{tabular}{lll}
\hline S/N & $\begin{array}{l}\text { Level I, land use/land } \\
\text { cover categories }\end{array}$ & Land use/land cover description \\
\hline I & Built up area & $\begin{array}{l}\text { Urban area, industrial layout, bare soil, residential, commercial, educational, infrastructure, road } \\
\text { network, pipeline, flow station, oil and gas facilities, flow lines, open and cleaned areas. }\end{array}$ \\
2 & Vegetation & This includes farmland, sparse vegetation and thick vegetation. \\
3 & Wetland & Permanent and seasonal wetlands, low-lying areas, Marshy land swamps. \\
4 & Water Body & Exposed water bodies within the study area including river, stream, rivulet creek
\end{tabular}

Source:Anderson et al. ${ }^{8}$

Photographs and coordinates of the various land-use land-covers were obtained with a hand-held GPS.

\section{Image geo-processing and wetland mapping}

The images were imported to ENVI 5.0 whereby the bands of the images were combined using COMPOSITE module and false colour composite images of bands 1, 2, 3 and 4 were selected for further analysis. The shape file of Study area boundary was generated in ArcGIS 10.1 and was used to clip the composite image of each year. Maximum likelihood supervised classifications were performed on the LANDSAT imageries. The per-pixel supervised classifications groups satellite image pixels with the same or similar spectral reflectance features into the same information categories. ${ }^{3}$ Four classes were identified namely built up area, wetland, water body, vegetation; and the description of each of the classes according to ${ }^{1}$ is shown in Table 2. The results were validated using the Kappa Index of Agreement (KIA) yielding an accuracy of 0.69 for year $1990,0.62$ for year 2000 , 0.58 for year 2010 and 0.73 for 2020 respectively. The classified landuse images were thereafter converted to vector format to compute the area of land-use which in each year in Hectares using spatial query module in ArcGIS 10.1. The wetlands were separated from other landuse to generate a spatial distribution map of wetlands of each of each of the community and simple arithmetic was used to determine the area, trend, direction and percentage of change of wetlands in Study area. The percentage of wetland lost to other land use was also computed in ArcGIS 10.1. The probability of wetlands changing to another land use was predicted to 2030, 2040 and 2050 using Markov chain model. Descriptive statistics were used to explain the values of wetland change and the percentage change in the wetland per year under consideration.

\section{Prediction of the trends in wetlands changes for period of thirty years using Markov chain predictive model}

A Markov chain can be described as a set of states $S=\left\{S_{0} S_{1}, S_{2}, \ldots, S_{r}\right\}$.

The process starts in one of these states and moves successively from one state to another, and each move is called a step. If the chain is currently in state then it moves to state $S j$ at the next step with a probability denoted by $P i j$, and this probability does not depend on which states the chain was in before the current state. The probabilities $P i j$ are called transition probabilities. The process can remain in the state it is in, and this occurs with probability Pii. An initial probability distribution, defined by $S(0)$, specifies the starting state.

Usually, this is conducted by specifying a particular state as the starting state.

\section{Transition probability matrix}

In a sequence of discrete time states, the probability of transitioning from state $i$ in $T_{m}$ state $j$ in $T_{m+1}$ in a single step is $P i j . P i j$ depends only on the state in $T_{m}$ and $T_{m+1}^{m+1}$. $P i j$ are arranged in sequence to give the following transition probability matrix:

$$
P=\left[\begin{array}{cccc}
P_{00} & P_{01} & \ldots & P_{0 m} \\
P_{10} & P_{11} & \ldots & P_{1 m} \\
\ldots & \ldots & \ldots & \ldots \\
P_{m 1} & P_{m 2} & \ldots & P_{m m}
\end{array}\right]
$$

Where:

$P i j$ is the transition probability of class's types from type $\mathrm{i}$ to $\mathrm{j}$. There are three assumptions: first, the Markov chain is stochastic. The probability of transition from state $\mathrm{i}$ to $\mathrm{j}$ is as follows: $P i j 1, \mathrm{j}=1,2$, $3, \ldots, \mathrm{m}$. Second, Markov chains are usually assumed to be a firstorder model so that the state of motion system in $\mathrm{T}+1$ depends only on that of T. Third, it is assumed that the transition probabilities do not change.

In accordance with the Markov stochastic process theory, we can use the probability matrix in the initial state to calculate the state transition probabilities given (here, we supposed it is the nth Markov state) from the initial state to the nth state and even a stable state. The formula of the nth state Markov transition probability was as follows:

$$
P_{i j}{ }^{(n)}=\sum_{k=0}^{m-1} P_{i k}^{(n-1)} P_{k j}^{(n-1)}
$$

Where:

$m$ is the number of rows or columns of the transition probability matrix, and the nth transition probability matrix is equivalent to the nth power of the first transition probability matrix (Ma, et al., 2012).

\section{Markov prediction}

According to the matrix of the initial $S(0)$ and the transition probability of the nth stage $P(n)$, we can calculate the future of wetland distribution area in the study area by using a computer simulation. The Markov simulation model $S(n)$ is as

Follows;

$$
S(n)=S(n-1) \times P(1)=S(0) \times P(n) .
$$




\section{The initial state}

The simulation steps are as follows: the first step is the determination of the initial state matrix. Dividing the Classes into a series of states and building the initial state matrix with the areas of each class for 2020 was as follows ( $\%$ of class):

$$
S(0)=\left[\begin{array}{l}
0.3629 \\
0.2669 \\
0.3436 \\
0.0265
\end{array}\right]=\left[\begin{array}{l}
\text { Built }- \text { up } \\
\text { Vegetation } \\
\text { Wetland } \\
\text { Waterbody }
\end{array}\right]
$$

\section{The transition probability matrix}

$$
P=\left[\begin{array}{lccc}
1.0000 & 0 & 0 & 0 \\
0.1434 & 0.8566 & 0 & 0 \\
0.0575 & 0 & 0.9425 & 0 \\
0 & 0.0460 & 0.0306 & 0.9233
\end{array}\right]
$$

\section{Evolution trends simulation}

The future wetland distribution area of change trend was calculated using equation (3), equation (4) and Table 3.

Table 3 The initial state transition probability matrix from 2010 to 2020

\begin{tabular}{lllll}
\hline Class & Built-up & Vegetation & Wetland & Water body \\
\hline Built-up & $\mathrm{I}$ & 0 & 0 & 0 \\
Vegetation & 0.1434 & 0.8566 & 0 & 0 \\
Wetland & 0.0575 & 0 & 0.9425 & 0 \\
Water body & 0 & 0.046 & 0.0306 & 0.9233
\end{tabular}

Source: (Author's Computation, 202I)

Predicted change for 2030 will be

$2030=\left[\begin{array}{l}0.3629 \\ 0.2669 \\ 0.3436 \\ 0.0265\end{array}\right] \times\left[\begin{array}{cccc}1.0000 & 0 & 0 & 0 \\ 0.1434 & 0.8566 & 0 & 0 \\ 0.0575 & 0 & 0.9425 & 0 \\ 0 & 0.0460 & 0.0306 & 0.9233\end{array}\right]$

$$
2030=\left[\begin{array}{l}
42.0976 \\
22.9846 \\
32.4711 \\
2.4465
\end{array}\right]
$$

Predicted change for 2040 will be

$$
\begin{gathered}
2040=\left[\begin{array}{l}
42.0976 \\
22.9846 \\
32.4711 \\
2.4465
\end{array}\right] \times\left[\begin{array}{lccc}
1.0000 & 0 & 0 & 0 \\
0.1434 & 0.8566 & 0 & 0 \\
0.0575 & 0 & 0.9425 & 0 \\
0 & 0.0460 & 0.0306 & 0.9233
\end{array}\right] \\
2040=\left[\begin{array}{l}
47.2602 \\
19.8001 \\
30.6804 \\
2.2588
\end{array}\right]
\end{gathered}
$$

Predicted change for 2040 will be

$$
\begin{aligned}
2050=\left[\begin{array}{l}
47.2602 \\
19.8001 \\
30.6804 \\
2.2588
\end{array}\right] \times\left[\begin{array}{lccc}
1.0000 & 0 & 0 & 0 \\
0.1434 & 0.8566 & 0 & 0 \\
0.0575 & 0 & 0.9425 & 0 \\
0 & 0.0460 & 0.0306 & 0.9233
\end{array}\right] \\
2050=\left[\begin{array}{l}
51.8631 \\
17.0638 \\
28.9868 \\
2.0856
\end{array}\right]
\end{aligned}
$$

\section{Results}

\section{The spatio-temporal changes of land use /land cover classes in the study area}

The results of the study showing the changes which has taken place over the 30 years period as deduced from the static distribution of land use/land cover for 1990, 2000, 2010 and 2020 are presented Figure $2-5$ and in Table 4.

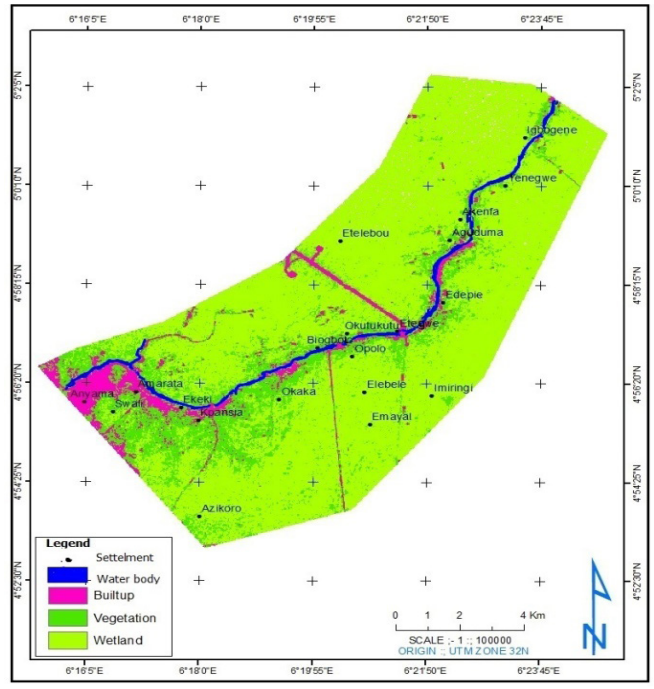

Figure 2 Classified imagery of 1990 of the study area.

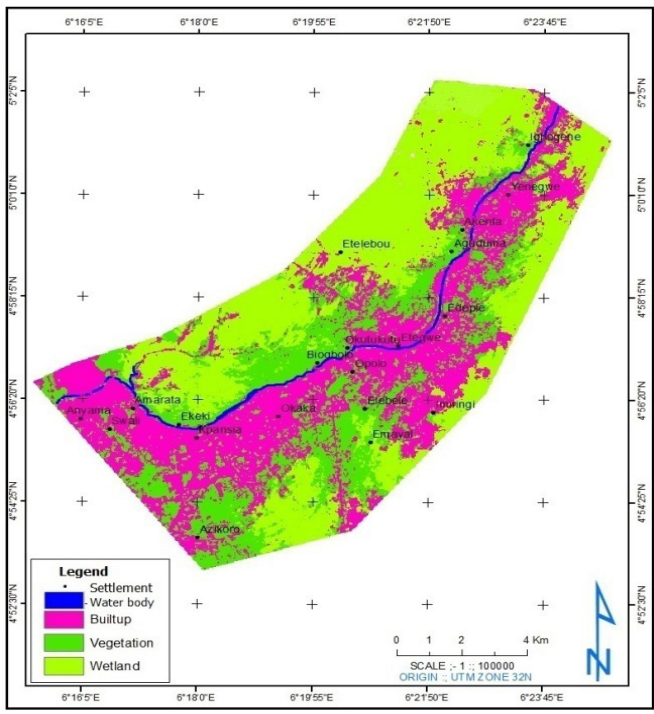

Figure 3 Classified imagery of 2000 of the study area. 


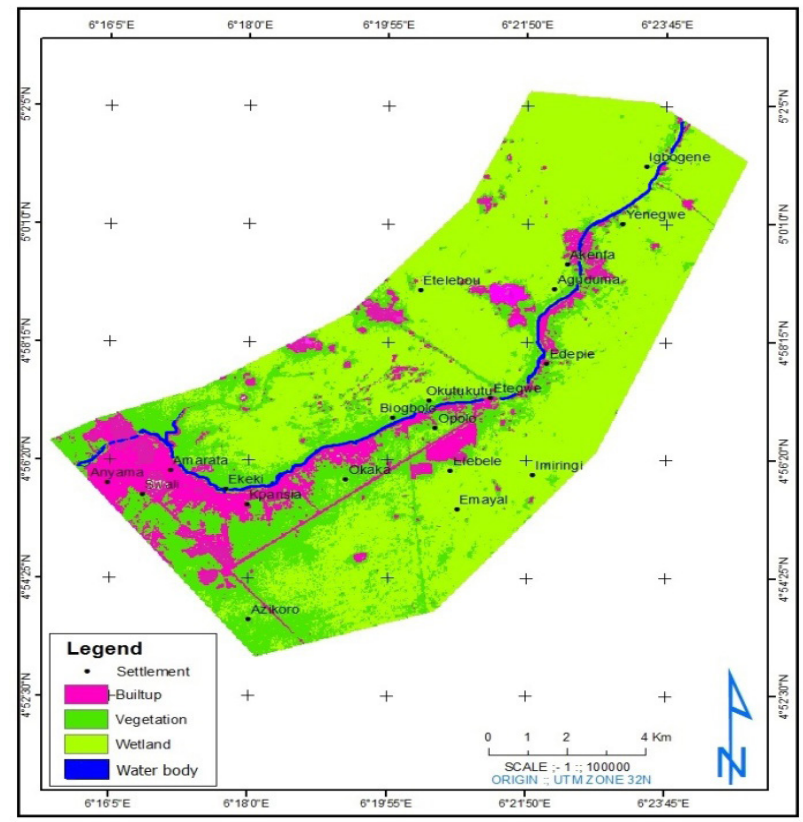

Figure 4 Classified imagery of 2010 of the study area.

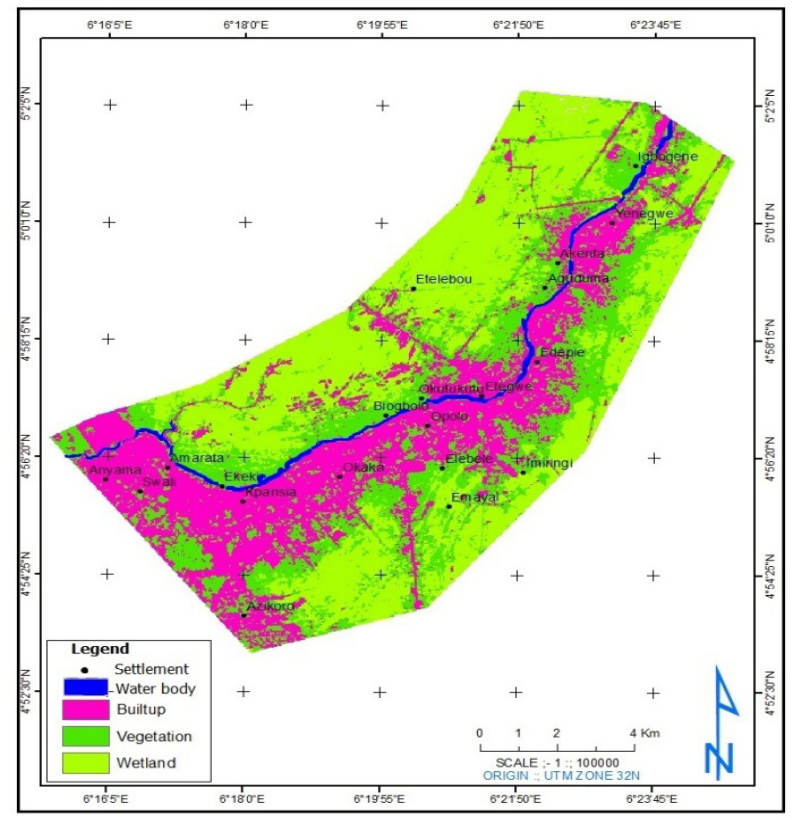

Figure 5 Classified imagery of 2020 of the study area.

Table 4 Spatial change detections of Land-use/land cover in the study area for each epoch

\begin{tabular}{lllllllll}
\hline Year & 1990 & \multicolumn{2}{c}{2000} & \multicolumn{2}{c}{2010} & \multicolumn{3}{c}{2020} \\
\hline LandUse /Land Cover classes & Area (Ha) & Area (\%) & Area (Ha) & Area (\%) & Area (Ha) & Area (\%) & Area(Ha) & Area (\%) \\
Built-up & 806.67 & 5.87 & 1685.25 & 12.264 & 4076.93 & 29.67 & 4987.37 & 36.29 \\
Vegetation & 2693.43 & 19.6 & 3661.38 & 26.645 & 4282.65 & 31.17 & 3667.77 & 26.69 \\
Wetland & 9867.12 & 71.81 & 8028.63 & 58.427 & 5008.7 & 36.45 & 4722.13 & 34.36 \\
Water body & 374.16 & 2.72 & 366.12 & 2.664 & 373.1 & 2.715 & 364.11 & 2.65 \\
Total & 13741.4 & 100 & 13741.4 & 100 & 13741.4 & 100 & 13741.4 & 100 \\
\hline
\end{tabular}


Spatial analysis of changes and inventory of wetlands in the study area (Figures 6-12) (Tables 5-7)

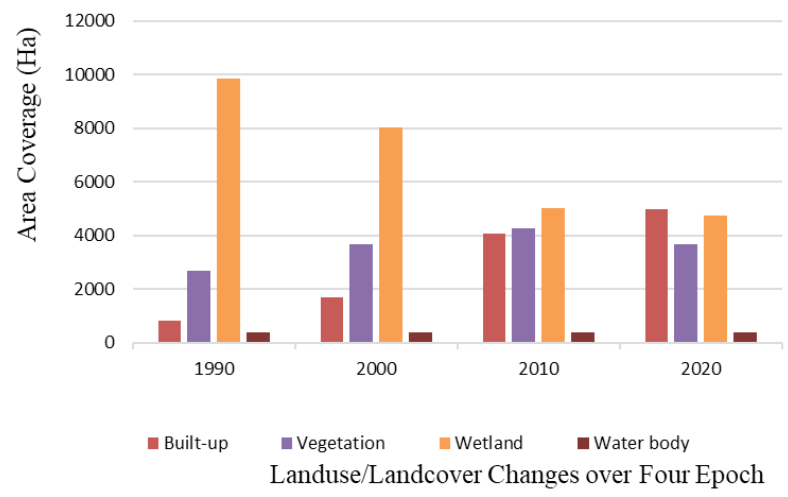

Figure 6 Graphical representations of land-use/land-cover changes.

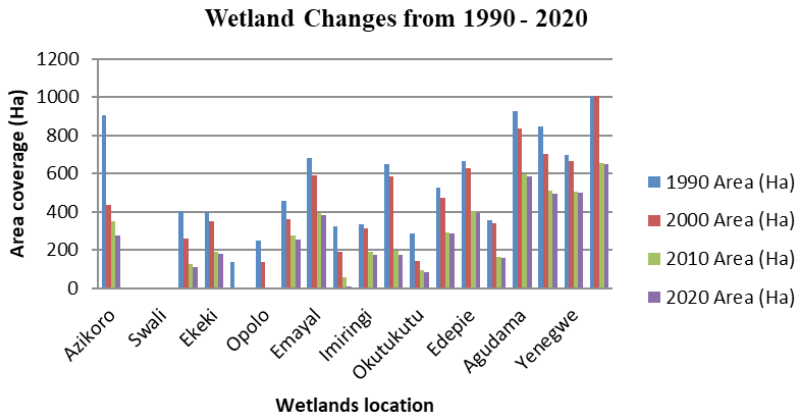

Figure 7 Graphical representation of wetland changes over the epochs.

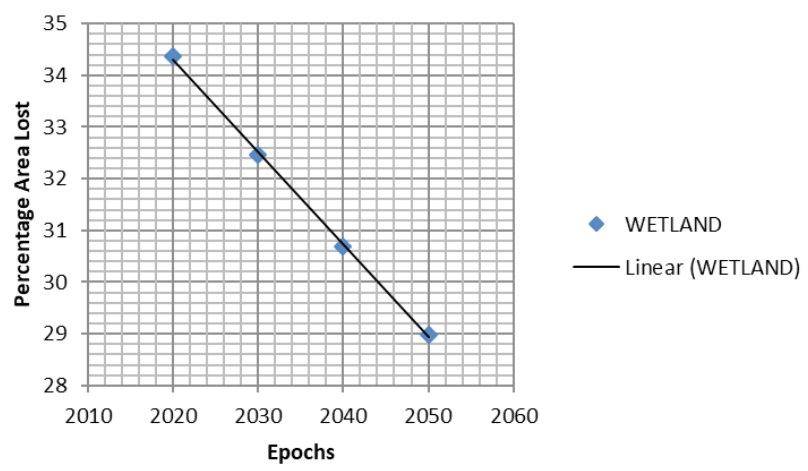

Figure 8 Graph Showing Predicted Lost in Wetland in View.

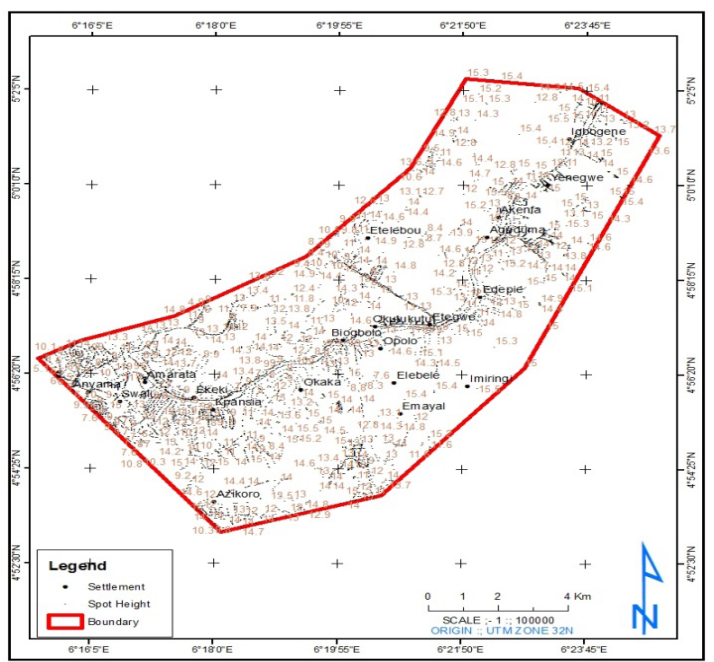

Figure 9 Spot Height of the study area.

Citation: Elemuwa IC, Hart L, Promise El. Spatial change detections and inventory of wetlands in Yenagoa Urban Area: Bayelsa State, Nigeria. MOJ Eco Environ Sci. 202।;6(6):230-240. DOI: I0.I5406/mojes.202I.06.00237 


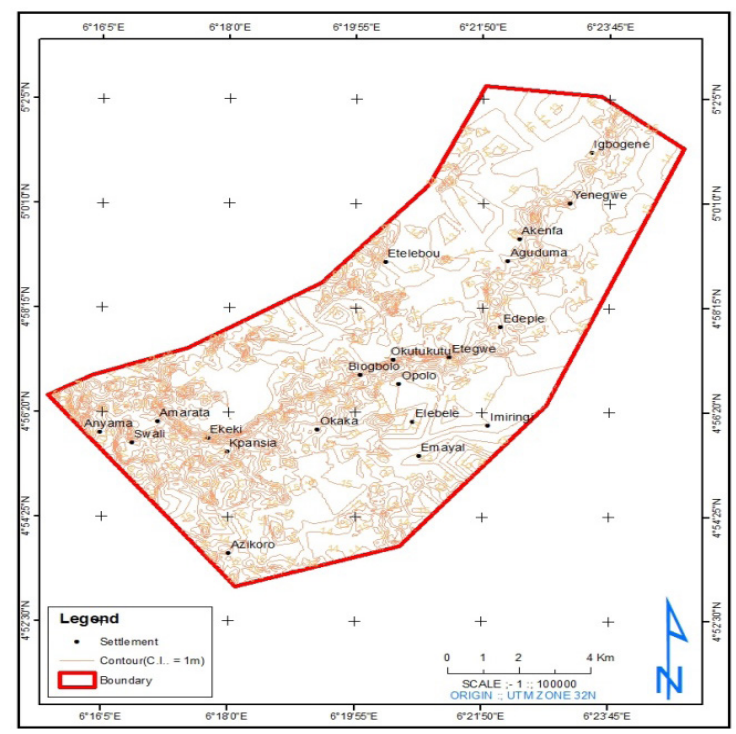

Figure 10 Contour map of the study area.

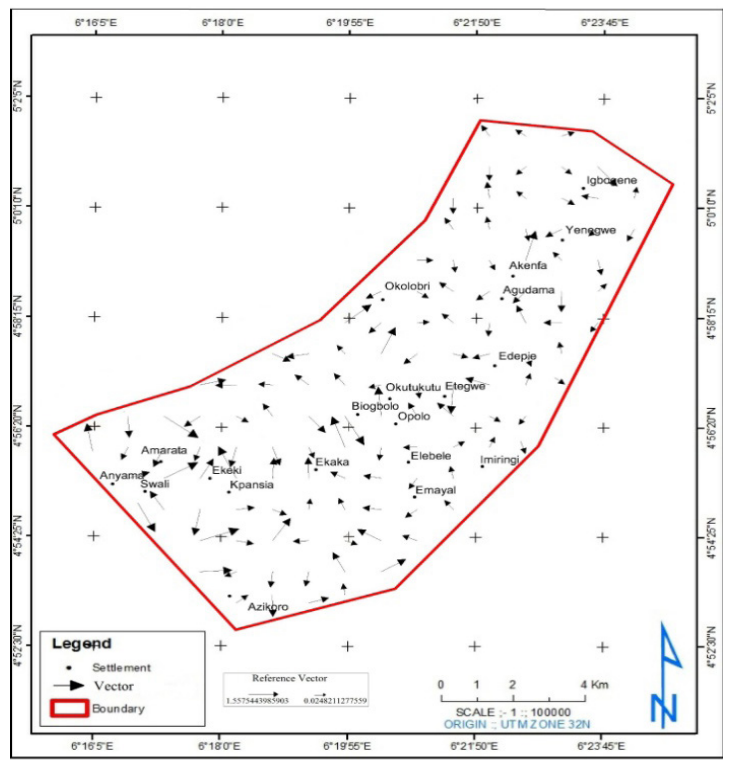

Figure I I Vector map of the study area.

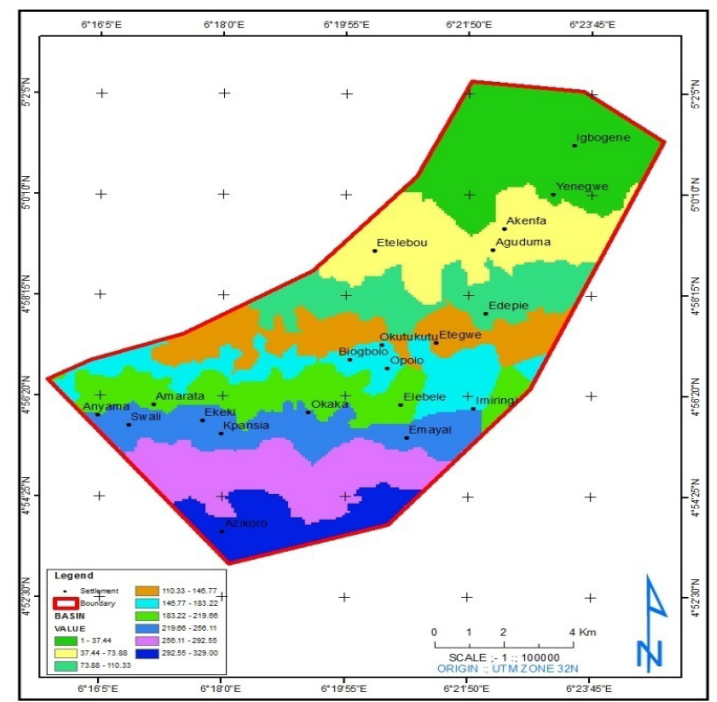

Figure I 2 Drainage Basin map of the study area.

Citation: Elemuwa IC, Hart L, Promise El. Spatial change detections and inventory of wetlands in Yenagoa Urban Area: Bayelsa State, Nigeria. MOJ Eco Environ Sci. 202I;6(6):230-240. DOI: 10.15406/mojes.2021.06.00237 
Table 5 Spatial change detection and inventory of wetlands locations

\begin{tabular}{|c|c|c|c|c|c|c|c|c|c|}
\hline Year & & 1990 & & 2000 & & 2010 & & 2020 & \\
\hline Wetlands & $\begin{array}{l}\text { Wetland spatial } \\
\text { information }\end{array}$ & $\begin{array}{l}\text { Area } \\
(\mathrm{Ha})\end{array}$ & $\begin{array}{l}\text { Area } \\
\text { (\%) }\end{array}$ & $\begin{array}{l}\text { Area } \\
(\mathrm{Ha})\end{array}$ & $\begin{array}{l}\text { Area } \\
\text { (\%) }\end{array}$ & $\begin{array}{l}\text { Area } \\
(\mathrm{Ha})\end{array}$ & $\begin{array}{l}\text { Area } \\
\text { (\%) }\end{array}$ & $\begin{array}{l}\text { Area } \\
(\mathrm{Ha})\end{array}$ & $\begin{array}{l}\text { Area } \\
\text { (\%) }\end{array}$ \\
\hline \multirow[t]{2}{*}{$\begin{array}{l}\text { Locations by } \\
\text { communities }\end{array}$} & Northings (m) & & & & & & & & \\
\hline & Easthings (m) & & & & & & & & \\
\hline \multirow[t]{2}{*}{ Azikoro } & 542785.21 & 904.89 & 9.17 & 436.46 & 5.43 & 352.19 & 7.03 & 273.99 & 5.8 \\
\hline & 199450.56 & & & & & & & & \\
\hline \multirow[t]{2}{*}{ Anyama } & 546451.45 & 4.95 & 0.05 & 0.36 & 0.01 & 0 & 0 & 0 & 0 \\
\hline & $197 \mid 48.97$ & & & & & & & & \\
\hline \multirow[t]{2}{*}{ Swali } & 544973.37 & 3.71 & 0.04 & I.I & 0.02 & 0 & 0 & 0 & 0 \\
\hline & 198308.94 & & & & & & & & \\
\hline \multirow[t]{2}{*}{ Amarata } & 547734.12 & 405.68 & 4.11 & 258.34 & 3.21 & 126.6 & 2.53 & 113.05 & 2.39 \\
\hline & 197972.87 & & & & & & & & \\
\hline \multirow[t]{2}{*}{ Ekeki } & 548691.41 & 401.3 & 4.07 & 350.58 & 4.37 & 192.17 & 3.84 & 179.67 & 3.8 \\
\hline & 199438.09 & & & & & & & & \\
\hline \multirow[t]{2}{*}{ Kpansia } & 545103.16 & 136.96 & 1.39 & 2.96 & 0.037 & 0 & 0 & 0 & 0 \\
\hline & 200889.56 & & & & & & & & \\
\hline \multirow[t]{2}{*}{ Opolo } & 547497.03 & 251.62 & 2.55 & 135.48 & 1.69 & 0 & 0 & 0 & 0 \\
\hline & 204492.92 & & & & & & & & \\
\hline \multirow[t]{2}{*}{ Okaka } & $546035.4 I$ & 454.77 & 4.61 & 360.37 & 4.48 & 273.62 & 5.46 & 253.99 & 5.38 \\
\hline & 202994.52 & & & & & & & & \\
\hline \multirow[t]{2}{*}{ Emayal } & 545515.55 & 683.36 & 6.92 & 589.81 & 7.34 & 395.14 & 7.89 & 384.63 & 8.14 \\
\hline & 205470.38 & & & & & & & & \\
\hline \multirow[t]{2}{*}{ Elebele } & 546433.57 & 326.16 & 3.3 & 190.76 & 2.376 & 59.81 & 1.19 & 11.19 & 0.24 \\
\hline & 205157.19 & & & & & & & & \\
\hline \multirow[t]{2}{*}{ Imiringi } & 545625.17 & 335.48 & 3.4 & 315.62 & 3.93 & 193.08 & 3.85 & 174.93 & 3.7 \\
\hline & 207204.47 & & & & & & & & \\
\hline \multirow[t]{2}{*}{ Biogbolo } & 547733.83 & 647.87 & 6.56 & 587.19 & 7.31 & 195.85 & 3.91 & 175.35 & 3.71 \\
\hline & 204903.08 & & & & & & & & \\
\hline \multirow[t]{2}{*}{ Okutukutu } & 548430.56 & 288.65 & 2.92 & 144.78 & 1.8 & 94.35 & 1.89 & 82.11 & 1.74 \\
\hline & 206117.61 & & & & & & & & \\
\hline \multirow[t]{2}{*}{ Etegwe } & 547948.61 & 524.98 & 5.32 & 474.93 & 5.91 & 294.52 & 5.88 & 289.41 & 6.13 \\
\hline & 206302.16 & & & & & & & & \\
\hline \multirow[t]{2}{*}{ Edepie } & 550233.52 & 665.79 & 6.75 & 629.97 & 7.85 & 403.48 & 8.05 & 394.63 & 8.36 \\
\hline & 208829.7| & & & & & & & & \\
\hline \multirow[t]{2}{*}{ Etelebou } & 550824.52 & 355.73 & 3.61 & 340.21 & 4.24 & 163.47 & 3.26 & 160.13 & 3.39 \\
\hline & 203150.46 & & & & & & & & \\
\hline \multirow[t]{2}{*}{ Agudama } & 552203.09 & 927.21 & 9.4 & 836.27 & 10.41 & 595.65 & 11.89 & 586.96 & 12.43 \\
\hline & 209165.63 & & & & & & & & \\
\hline \multirow[t]{2}{*}{ Akenfa } & 552203.09 & 844.31 & 8.56 & 705.1 & 8.78 & 508.86 & 10.16 & 495.07 & 10.48 \\
\hline & 209165.64 & & & & & & & & \\
\hline
\end{tabular}




\begin{tabular}{|c|c|c|c|c|c|c|c|c|c|}
\hline Year & & 1990 & & 2000 & & 2010 & & 2020 & \\
\hline Wetlands & $\begin{array}{l}\text { Wetland spatial } \\
\text { information }\end{array}$ & $\begin{array}{l}\text { Area } \\
(\mathrm{Ha})\end{array}$ & $\begin{array}{l}\text { Area } \\
(\%)\end{array}$ & $\begin{array}{l}\text { Area } \\
(\mathrm{Ha})\end{array}$ & $\begin{array}{l}\text { Area } \\
(\%)\end{array}$ & $\begin{array}{l}\text { Area } \\
(\mathrm{Ha})\end{array}$ & $\begin{array}{l}\text { Area } \\
(\%)\end{array}$ & $\begin{array}{l}\text { Area } \\
(\mathrm{Ha})\end{array}$ & $\begin{array}{l}\text { Area } \\
\text { (\%) }\end{array}$ \\
\hline \multirow[t]{2}{*}{$\begin{array}{l}\text { Locations by } \\
\text { communities }\end{array}$} & Northings (m) & & & & & & & & \\
\hline & Easthings (m) & & & & & & & & \\
\hline \multirow[t]{2}{*}{ Yenegoa } & 553068.94 & 696.08 & 7.05 & 664.33 & 8.27 & 505.3 & 10.09 & 498.13 & 10.55 \\
\hline & 209841.81 & & & & & & & & \\
\hline \multirow[t]{2}{*}{ Igbogene } & 555075.37 & 1007.56 & 10.21 & 1004.03 & 12.5 & 654.57 & 13.07 & 648.87 & 13.74 \\
\hline & 210895.55 & & & & & & & & \\
\hline Total & & 9867.12 & 100 & 8028.63 & 100 & 5008.7 & 100 & 4722.13 & 100 \\
\hline
\end{tabular}

Table 6 Predicted change from 2030 -2050 using Markov chains

\begin{tabular}{lllllll}
\hline Year & $\mathbf{2 0 3 0}$ & & $\mathbf{2 0 4 0}$ & \multicolumn{2}{c}{2050} \\
\hline Land use /Land cover classes & Area (Ha) & Area (\%) & Area (Ha) & Area (\%) & Area (Ha) & Area (\%) \\
\hline Built-up & 5784.81 & 42.09 & 6494.27 & 47.26 & 7126.802 & 51.86 \\
Vegetation & 3158.4 & 22.98 & 2720.8 & 19.8 & 2344.802 & 17.06 \\
Wetland & 4461.97 & 32.47 & 4215.96 & 30.68 & 3983.186 & 28.99 \\
Water body & 336.18 & 2.44 & 310.39 & 2.26 & 286.5902 & 2.09 \\
Total & 13741.4 & 100 & 13741.4 & 100 & 13741.4 & 100 \\
\hline
\end{tabular}

Source: (Author's Computation, 202I)

Table 7 Prediction of Changes in wetlands for a period of 30years in the study area

\begin{tabular}{|c|c|c|c|c|c|c|c|c|c|c|}
\hline Year & 2020 & 2030 & $\%$ Change & 2030 & 2040 & $\%$ Change & 2040 & 2050 & $\%$ Change & $\begin{array}{l}\text { Total \% } \\
\text { Change }\end{array}$ \\
\hline $\begin{array}{l}\text { LandUse /Land } \\
\text { Cover classes }\end{array}$ & $\begin{array}{l}\text { Area } \\
(\%)\end{array}$ & $\begin{array}{l}\text { Area } \\
(\%)\end{array}$ & & $\begin{array}{l}\text { Area } \\
(\%)\end{array}$ & $\begin{array}{l}\text { Area } \\
(\%)\end{array}$ & & Area (\%) & $\begin{array}{l}\text { Area } \\
(\%)\end{array}$ & & \\
\hline Wetland & 34.36 & $32.47 I I$ & -5.49738 & 32.4711 & 30.6804 & $-5.5 \mid 475$ & 30.6804 & 28.9868 & -5.52014 & -16.53 \\
\hline
\end{tabular}

Source: (Author's Computation, 202I)

\section{Discussion}

Table 4 shows that in 1990, built up area occupied the third highest classes with $5.870 \%(806.67 \mathrm{Ha})$ of the total classes. Wetlands ecosystem occupied $71.806 \%(9867.12 \mathrm{Ha})$ of the total classes. The Vegetation cover occupied $19.601 \%(2693.43 \mathrm{Ha})$ of the total Classes and water body occupied $2.72 \%(374.16 \mathrm{Ha})$ of the total class.

In 2000 , built up area rise to $12.25 \%(1685.25 \mathrm{Ha})$, the wetlands maintain a small reduction of $58.427 \%(8028.63 \mathrm{Ha})$. The vegetation cover occupied $26.64 \%$ (3661.38 Ha). The water body occupied $2.66 \%$ (366.12 Ha); this shows a sharp reduction from the 1990. The table also shows that in the year 2010, built up area covers $29.67 \%$ $(4987.37 \mathrm{Ha})$ of the total class with a high increase. The wetlands covered $36.45 \%$ (5008.70Ha). Vegetation covered $31.166 \%$ (4282.65 $\mathrm{Ha})$ of the total class with reduction from 2000. The water body covered $2.715 \%(373.1 \mathrm{Ha})$.

In 2020, the built-up area covers $36.29 \%$ (4987.37Ha) of the total land area. Degradation of wetland becomes very high. Wetlands covered $34.36 \%(4722.13 \mathrm{Ha})$. The vegetation covered $26.69 \%$ ( $3667.77 \mathrm{Ha})$. The water body occupied $2.650 \%$ (364.11Ha); Figure 6 shows the statically model of land-use/land-cover as against Area Coverage.
Wetland in the study area varies in sizes on the respective location, the various locations on the study area involves about twenty settlements as shown in the table 3.3. The wetland changes from 1990 -2020 with respect to the total area of study area. The table shows the total area of wetland in 1990 of the twenty settlements to be 9867.12 Ha. In 2000, Wetland total area was $8028.63 \mathrm{Ha}$ as an indication of loss of wetland due to impact on other landuse/landcover, such as the built-up area and the vegetation cover. However, 1n 2000, wetland degradation increased tremendously thereby having the total area to be $5008.7 \mathrm{Ha}$; this is as a result of urban growth and Vegeation cover such as the agricultural activities. In 2020, wetland continues to suffer loss. The rate of reclamation was in increased thereby reduces the size of wetland to $4722.13 \mathrm{Ha}$.

Is it seen in table 3.2 the year 1990 shows location with maximum area of wetland was Igbogene with area coverage of 1007.566ha, while locations such as Swali and Anyama have a minimum area with $3.709 \mathrm{Ha}$ and $4.956 \mathrm{Ha}$ respectively.

In 2010, wetlands at Igbogene reduced based on the total area of wetland in the study area. Igbogene have maximum area of $10.21 \mathrm{Ha}$, while the minimum locations such as Swali and Anyama have almost vanished wetland of $1.10 \mathrm{Ha}$ and $0.36 \mathrm{Ha}$ respectively. In 2010, wetland locations at Anyama, swali, kpansia and Opolo was totally lost to 
other class of land use and land cover, Igbogene which happened to be the location with maximum area covered by wetland, reduced in size to $654.57 \mathrm{Ha}$.

In the year 2020, wetlands completely loss at about four settlements, and wetland locations continued degrading in total area. This is an implication of Urban growth (Built-up) which was the only class of the land-use / land-cover that continuously impacted negatively on wetland in the study area.

Table 5 analyses clearly on the Changes in wetlands over four Epochs, and the change between $1990-2000,2000-2010$, and 2010 -2020 based on the analysis of wetlands location as shown in Table 6. Negative symbols in the statistics indicated a loss in the class. (Oludare, et al., 2015).

The results from table 4.2.1 revealed that from 1990 -2000, wetlands at Azikoro had $-468.5 \mathrm{Ha}(-51.75 \%)$ loss with annual rate of change of -5.177 , Anyama; wetlands continues to loss $-4.59 \mathrm{Ha}(-92.62 \%)$ lost with annual rate of change of -9.263 . at Swali, the wetlands reduces with the values of $-2.60 \mathrm{Ha}(-70.17 \%)$ loss with annual rate of -7.018 . Amarata wetlands reduces with a value $-147.4 \mathrm{Ha}(-36.35 \%)-3.632$.At Ekeki wetlands reduced with a value of $-50.72 \mathrm{Ha}(-12.63 \%)-1.264$. at Kpansia wetlands reduced to $-134 \mathrm{Ha}(-97.838 \%)-9.784$. at Okaka wetlands reduced with values of $-94.4 \mathrm{Ha}(-20.76 \%)-2.076$. Emayal wetlands reduced with the value of $-93.55 \mathrm{Ha}(-13.68 \%)-1.369$. at Elebele wetlands reduced with the values of $-135.4 \mathrm{Ha}(-41.51 \%)$ -4.151 . wetland at Imiringi reduced with the values of $-19.86 \mathrm{Ha}$ $(-5.91983 \%)$ loss with annual rate of -0.592 . Biogbolo wetland reduced with the values of $-60.68 \mathrm{H}(-9.36 \%)$ loss with annual rate of -0.937 . wetland at Okutukutu reduced with a values of $-143.9 \mathrm{Ha}(-$ $49.84 \%)$ loss with annual rate of -4.984 . at Etelebou wetland reduced with the values of $-15.53 \mathrm{Ha}(-4.36 \%)$ loss with annual rate of change of -0.437 . at Edepie wetlands reduced with a value of $-35.82 \mathrm{Ha}(-$ $5.38 \%$ ) loss with annual rate of change of -0.538 . at Etegwe wetland reduced with the values of $-50.05 \mathrm{Ha}(-9.53 \%)$ loss with annual rate of change of -0.953 . At Agudama wetland reduced with the values of $-90.95 \mathrm{Ha}(-9.80 \%)$ loss with annual rate of change of -0.981 . at Akenfa wetlands reduced with the values $-139.2 \mathrm{Ha}(-16.4873 \%)$ loss with annual rate of change of -1.64 . at Yenegwe wetland reduced with the values of $-31.74 \mathrm{Ha}(-4.56 \%)$ loss with annual rate of change of -0.456 . at Igbogene wetland reduced with the values of $-3.534 \mathrm{Ha}(-$ $0.35 \%$ ) loss with annual rate of change of -0.035 .

From 2000 -2010, wetlands were serious impacted by built-up area and vegetation cover. Wetlands continuously losses it size at various location in the study area such as in Azikiro, its wetland reduced with the values of $-84.206 \mathrm{Ha}(-19.3 \%)$ loss with the annual rate of change of -1.92 . at Anyama, the wetland reduced with the values of $-0.33 \mathrm{Ha}$ $(-100 \%)$ loss with the annual rate of change of -10 . At Swali, wetlands reduced with the values of $-1.1061 \mathrm{Ha}(-100 \%)$ loss with the annual rate of change of -10. At Amarata, wetland reduced with the values of $-131.72 \mathrm{Ha}(-50.99 \%)$ loss with the annual rate of change of -5.09899 . At Ekeki, wetland reduced with the values of $-158.41 \mathrm{Ha}(-45.18 \%)$ loss with the annual rate of change of -4.51 . at Kpansia, wetland reduced with the values of $-2.97 \mathrm{Ha}(-100 \%)$ loss with the annual rate of change of -10 . At Okaka, wetlands reduced with the values of $-86.747 \mathrm{Ha}(-24.07 \%)$ having the annual rate of change of -2.40 . In summary, no other land use classes experienced this negative change as the wetland in the study area. The total percentage change and total rate of change for the wetland trend from $1990-2020$ as shown in the table 4.2.1 indicated that Azikoro wetlands have total \%change of93.27 and total rate of change of -9.327 . Anyama wetland have total $\%$ change of -192.63 and total rate of change of -19.26 , Swali wetland have a total \% Change of -170.18 and total rate of change of -17.02 . Wetland at Amarata has a total \% Change of -98.02 and the total rate of change-9.802. Wetland at Ekeki has a total \%change of -64.33 and total rate of -6.43 , Kpansia wetland have total \%change of -197.84 and total annual rate of change of -19.78 . Wetland at Okaka has the total \%change of -52.005 and total annual change of -5.21 . Emayal wetland has the total \%change of -46.961 and total annual rate of change of -4.91 . Elebele wetland has the total \%change of -191.45 and total annual rate of change of -19.15.Imiringi wetland have the total $\%$ change of -54.14 and total annual rate of change of -5.414 . Wetlands at Biogbolo have the total \%change of -77.06 and total annual rate of change of -8.648 . Okutukutu wetland have the \%change of -97.67 and total annual rate of change of -9.765 . Etegwe wetland have the total $\%$ change of -49.26 and total annual rate of change of -4.92 . at Edepie wetland have the total \%change of -41.55 and total annual rate of change of -4.35 . Agudama wetland have the total \%change of -40.04 and total annual rate of change of -4.04 . Akenfa wetlands have the total \%change of -44.59 and total annual rate of -4.70 . Yenegwe wetland have the total \%change of -29.91 and total annual rate of change of -2.99 . Igbogene wetlands have the \%change of-36.03 and the total annual rate change of -3.603 .

Specifically, we simulated the evolution trend of the Classes distribution area in study area using the Markov model. A review of the table 3.8 highlighted, predicted that in 2030 , the built -up area was expected to occupy the largest area with $42.0 .098 \%$ of the total classes. The Vegetation cover was predicted to occupy $22.985 \%$ of the total Classes and water body to occupy $2.4465 \%$, while Wetlands was predicted to occupy $32.471 \%$ of the total classes.

In 2040 , built up area was predicted to cover $47.26 \%$ of the total class. The vegetation cover is predicted to occupy $19.8 \%$ of the total class. Wetland is expected to keep suffering loss with $30.68 \%$. The water body was predicted tooccupy $2.2588 \%$ of the total area.

In the year 2050, the built up area is expected to cover $51.86 \%$ of the total class with a high increase. The wetlands were predicted reduce to $28.99 \%$. The vegetation cover is expected to cover $17.06 \%$ of the total class with reduction from 2040. The water body was predicted to cover $2.086 \%$ of the total area.

Since emphasis of the research work was on wetlands. The table 3.4 shows the predicted changes from year (epoch) of 2020- 2030, 2030- 2040 and 2040-2050 on the extent of wetlands over thirty years period in the study area. From 2020- 2030, it was expected that the loss of wetland in the study area will amount to $-5.497 \%$ of total class area. From 2030- 2040, Wetland was expected to continually loss due to pressure from urban growth with $-5.515 \%$ of lost from the total class area. From 2040-2050, the degradation was expected to continue at about- $5.520 \%$ loss from the total class area.

The surface flow direction of terrain of the study area in Figure 8 was produced using elevation data extracted from the satellite imageries of each epoch. Elevation has significant influence on wetland. Because water moves under the force of gravity and will generally moves from highland to low land. Thus, in any given environment, lowland areas are thus favorable for identifying wetlands. Elevation data was extracted from SRTM Digital Elevation Model obtained from website of Global land cover facility, university of Maryland. Elevation for the study area was used to produce a Spots height map, the Contour map, Victor map, Drainage Basin and the Slope map as shown in Figures $8-12$, the spot heights ranges from $2.80 \mathrm{~m}$ to $15.90 \mathrm{~m}$. It has a mean of $13.00 \mathrm{~m}$ and a standard deviation of $2.68 \mathrm{~m}$. The vector map (Figure 10) shows the flow direction of the study area having reference vectors from 1.55 as maximum to 0.024 as minimum. ${ }^{8-11}$ 


\section{Conclusion}

The unavoidable or inescapable nature of change in time and space calls for planning in the Yenegoa local government area most especially the urban environment. The study reveals a very increasing rate of wetland reduction and expansion of built-up area. Adequate planning is needed to protect and conserve wetland ecosystem. If no adequate measures are been put in place, our wetland resources in the urban area may grossly become extinct.

\section{Recommendations}

Higher resolution satellite imageries should be used for further studies and to validate the results of this study and measures should be put in place to monitor and regulate wetlands reclamation to forestall the likely incidence of flood and other natural disasters in the study area.

\section{Acknowledgments}

None.

\section{Funding}

None.

\section{Conflicts of interest}

All author listed here declare no conflict of interest exists.

\section{References}

1. Ramsar I. The ramsar convention manual: a guide to the convention on wetlands. 6th edn. Ramsar Convention Secretariat, Gland; 1971. 112 p.
2. Wali E, Phil-Eze PO, Nwankwoala HO. Saltwater- Freshwater wetland ecosystem and urban land use change in Port Harcourt metropolis, Nigeria. Earth Sciences Malaysia. 2018;2(1):1-7.

3. Mathews GVT. The ramsar convention on wetlands: Its history and development. Luthi; 1993.

4. E Ramsar. Gland (Switzerland): Ramsar Convention Bureau.

5. LI J, Chen W. A Rule- based method for mapping Canada's Wetland Using Optical, Radar and DEM Data. International Journal of Remote Sensing. 2005;26(22):5051-5069.

6. UNEP. Environmental assessment of Ogoni land", 1-262. United Nation Environmental Programme (UNEP): Nairobi. 2011.

7. Ohimain EL, Imoobe TOT, Benka-Coker. Impact of dredging on zooplankton communities of Warri Rivers, Niger -Delta. African Journal of Environmental Pollution and Health. 2002;1:37-45.

8. Anderson JR, Hardy EE, Roach JT, et al. A landuse and land cover classification system for use with remote sensor data. Geological Survey Professional Paper 964. A revision of the land use classification system as presented in U.S. Geological Survey Circular; 2001.

9. Keddy PA. Wetland Ecosystem: principles and conservation (2nd edn. New York: Cambridge University Press; 2010. 49 p.

10. Niger Delta Development Commission. Niger delta regional development plan. Printing development commission limited, NDDC, Port-Harcourt, Nigeria; 2006. 258 p.

11. Turner MH, Gannon R. Major causes of wetland loss and degradation. Wetlands Loss and Degradation. 2017. 